\title{
'LAETITIA' PLUMS STORED IN CONTROLLED ATMOSPHERES COMBINED WITH INDUCTION OF MASS LOSS AND ETHYLENE MANEGEMENT ${ }^{1}$
}

\author{
CRISTIANO ANDRÉ STEFFENS ${ }^{2 *}$, CASSANDRO VIDAL TALAMINI DO AMARANTE ${ }^{2}$, BRUNO PANSERA \\ ESPINDOLA ${ }^{3}$, ANGÉLICA SCHMITZ HEINZEN $^{2}$, AURI BRACKMANN ${ }^{4}$, VANDERLEI BOTH $^{4}$
}

\begin{abstract}
Two experiments were conducted to evaluate the relative effects of controlled atmosphere (CA) associated with 1-methylcyclopropene (1-MCP; $1.0 \mu \mathrm{L} \mathrm{L}^{-1}$ ), induction of mass loss (IML; $\%$ ), and low ethylene ( $\mathrm{LE} ;<0.04 \mu \mathrm{L} \mathrm{L}^{-1}$ of $\mathrm{C}_{2} \mathrm{H}_{4}$ ) on the quality preservation of 'Laetitia' plums. In experiment 1 (2010), the treatments evaluated were cold storage $(\mathrm{CS} ; 21.0 \mathrm{kPa} \mathrm{O}+<0.03 \mathrm{kPa} \mathrm{CO}), \mathrm{CA} 1\left(1 \mathrm{kPa} \mathrm{O}+1 \mathrm{kPa} \mathrm{CO}_{2}\right)$, $\mathrm{CA} 1+1-\mathrm{MCP}, \mathrm{CA} 1+\mathrm{IML}$, and CA1 + LE. In experiment 2 (2011), the treatments evaluated were CS, CA2 $\left(2 \mathrm{kPa} \mathrm{O}_{2}+2 \mathrm{kPa} \mathrm{CO} 2\right), \mathrm{CA} 2+\mathrm{IML}$, and CA2 + 1-MCP. In both experiments, the fruit were stored at $0.5 \pm$ $0.1{ }^{\circ} \mathrm{C}$ and $96 \pm 2 \% \mathrm{RH}$. CA storage delayed fruit ripening in both atmosphere conditions evaluated and reduced the internal browning of the 'Laetitia' plums, particularly in CA2. 1-MCP, LE, and IML had additional effects to $\mathrm{CA} 1$ on preserving flesh consistency. 1-MCP, irrespective of the CA condition, and IML, in CA1, reduced internal browning. CA1, regardless of the complementary technologies, reduced the incidence of decay and fruit cracking.
\end{abstract}

Keywords: Prunus salicina. Internal browning. Physiological disorder. Ripening.

\section{AMEIXAS 'LAETITIA’ ARMAZENADAS EM ATMOSFERA CONTROLADA COM INDUÇÃO DE PERDA DE MASSA E MANEJO DO ETILENO}

RESUMO - Foram conduzidos dois experimentos com o objetivo de avaliar o efeito da atmosfera controlada (AC) associada ao 1-metilciclopropeno (1-MCP; $\left.1,0 \mu \mathrm{L} \mathrm{L}^{-1}\right)$, à indução de perda de massa (IPM; $2 \%$ ) e ao baixo etileno $\left(\mathrm{BE} ;<0,04 \mu \mathrm{L} \mathrm{L}^{-1}\right.$ de $\mathrm{C}_{2} \mathrm{H}_{4}$ ) sobre a manutenção da qualidade de ameixas 'Laetitia'. No experimento 1, em 2010, os tratamentos avaliados foram armazenamento refrigerado (AR; $21 \mathrm{kPa} \mathrm{O}_{2}+<0,03$ $\mathrm{kPa} \mathrm{CO}$ ), AC1 (1 kPa O $\left.2+1 \mathrm{kPa} \mathrm{CO}_{2}\right), \mathrm{AC} 1+1-\mathrm{MCP}, \mathrm{AC} 1+\mathrm{IPM}$ e AC1+BE. No experimento 2, em 2011, os tratamentos foram AR, AC2 $\left(2 \mathrm{kPa} \mathrm{O}_{2}+2 \mathrm{kPa} \mathrm{CO}\right)$, AC2+1-MCP e AC2+IPM. Em ambos os experimentos, os frutos foram armazenados a $0,5 \pm 0,1{ }^{\circ} \mathrm{C}$ e $96 \pm 2 \%$ de umidade relativa. A AC retardou o amadurecimento, em ambas as atmosferas avaliadas, e reduziu o escurecimento de polpa de ameixas 'Laetitia', especialmente na $\mathrm{AC2}$. O 1-MCP, o BE e a IPM apresentaram efeito adicional à AC1 na manutenção da consistência da polpa. $\mathrm{O}$ 1-MCP, independente da condição de AC, e a IPM, na condição de AC1, reduziram o escurecimento da polpa. A AC1, independente do uso de tecnologias complementares, reduziu a incidência de podridões e de rachaduras.

Palavras-chave: Prunus salicina. Escurecimento da polpa. Distúrbio fisiológico. Amadurecimento.

\footnotetext{
${ }^{*}$ Corresponding author

${ }^{1}$ Received for publication in 04/07/2016; accepted in 02/16/2017.

${ }^{2}$ Department of Agronomy, Universidade do Estado de Santa Catarina, Lages, SC, Brazil; cristiano.steffens@udesc.br, cassandro.amarante@udesc.br, angelica_heinzen@hotmail.com.

${ }^{3}$ Department of Agronomy, Instituto Federal Catarinense, Santa Rosa do Sul, SC, Brazil; bruno.pansera@santarosa.ifc.edu.br.

${ }^{4}$ Department of Plant Science, Universidade Federal de Santa Maria, Santa Maria, RS, Brazil; auribrackmann@gmail.com, vanderleiboth@yahoo.com.br.
} 


\section{INTRODUCTION}

Internal browning is a process known as cold damage that affects stored plums (SINGH; SINGH, $2013 \mathrm{a}, \mathrm{b})$. This process is caused by an oxidative process related to production of reactive oxygen species and reduction of efficiency of antioxidant systems, with consequent damages to cell membranes (SINGH; SINGH, 2012; 2013a, b).

Controlled atmosphere (CA) prolongs the conservation of 'Laetitia' plums (STEFFENS et al., 2013; 2014). According to Steffens et al. (2014), atmospheric conditions with $1 \mathrm{kPa} \mathrm{O}_{2}+1 \mathrm{kPa} \mathrm{CO}_{2}$ and $2 \mathrm{kPa} \mathrm{O}_{2}+2 \mathrm{kPa} \mathrm{CO}_{2}$ are considered the best conditions for 'Laetitia' plum storage. However, even under these conditions, internal browning of 'Laetitia' plums may still occur (STEFFENS et al., 2013; 2014).

Internal browning may be aggravated by the effect of ethylene (CANDAN; GRAEL; LARRIGAUDIÉRE, 2011; CORRÊA et al., 2011) and lower diffusion of $\mathrm{O}_{2}$ and $\mathrm{CO}_{2}$ gases through the flesh in stored fruits (BRACKMANN et al. 2014). Thus, the use of complementary technologies to CA, such as 1-methylcyclopropene (1-MCP), induction of mass loss (IML) and low ethylene (LE) may be alternatives to reduce the occurrence and severity of internal browning.

Several studies have shown the effect of 1-MCP on ripening delay and post-harvest fruit quality maintenance (CANDAN; GRAEL; LARRIGAUDIÉRE, 2011; CORRÊA et al., 2011; MANGANARIS et al., 2008). Since internal browning in plums is aggravated by ethylene, $1-\mathrm{MCP}$ may reduce its occurrence (CANDAN; GRAEL; LARRIGAUDIÉRE, 2011; CORRÊA et al., 2011). On the other hand, CA combined with LE may present similar effects to 1-MCP in 'Laetitia' plums.

Diffusion of gases through fruit flesh is essential to prevent an excessive decrease in $\mathrm{O}_{2}$ and increase in internal $\mathrm{CO}_{2}$ levels, which may affect the postharvest quality maintenance (BRACKMANN et al., 2014). Therefore, IML can probably contribute to reduce internal browning of stored plums in CA, since this technique possibly results in the removal of water from intercellular spaces of the fruit flesh tissue, facilitating the diffusion of gases through the flesh to the storage atmosphere. In cold storage (CS), IML contributes to reduce internal browning in Laetitia plums (ALVES et al., 2009), however, the effect of this technique on plums stored in CA was not yet evaluated.

Some studies were carried out on 'Laetitia' plums stored in CA (ALVES et al., 2010a; STEFFENS et al., 2013; 2014), however, they aimed to identify ideal conditions of $\mathrm{O}_{2}$ and $\mathrm{CO}_{2}$ for storage. Evaluations of complementary techniques, such as 1-MCP, LE and IML, combined with ideal CA conditions, on storage of 'Laetitia' plums were not yet conducted, except for 1-MCP. However, the positive results of IML and LE in fruits in CS, especially on internal browning (ALVES et al., 2009), indicate a potential synergy between these technologies and CA to control fruit ripening and reduce internal browning.

The objective of this work was to evaluate the effect of $\mathrm{CA}$, with ideal $\mathrm{O}_{2}$ and $\mathrm{CO}_{2}$ conditions, combined with application of 1-MCP, IML and LE, on postharvest quality maintenance of 'Laetitia' plums.

\section{MATERIAL AND METHODS}

The 'Laetitia' plum fruits were harvested at commercial harvest stage, i.e., when $50 \%$ of the fruit epidermis was red, in 2010 (Experiment 1) and 2011 (Experiment 2) in a commercial orchard in Vacaria, State of Rio Grande do Sul, Brazil (28 $40^{\prime} 48.65^{\prime \prime S}$ and $50^{\circ} 47^{\prime} 11.42^{\prime \prime} \mathrm{W}$, average altitude of $973 \mathrm{~m}$ ). The fruits were taken to a laboratory and defective fruits were discarded, then, experimental samples were homogenized and placed in $0.45 \mathrm{~m}^{3}$ experimental micro-chambers, which were inside $45 \mathrm{~m}^{3}$ cold rooms, to applying the treatments.

The treatments of Experiment 1 were cold storage (21 $\left.\mathrm{kPa} \mathrm{O}_{2}+\mathrm{CO}_{2}<0.03 \mathrm{kPa}\right)(\mathrm{CS})$, controlled atmosphere (CA1) (1 kPa of $\mathrm{O}_{2}+1 \mathrm{kPa}$ of $\left.\mathrm{CO}_{2}\right), \mathrm{CA} 1$ combined with 1-methylcyclopropene $\left(1 \mu \mathrm{L} \mathrm{L}^{-1}\right)$ (CA1+1-MCP), CA combined with induction of mass loss $(2 \%)(\mathrm{CA} 1+\mathrm{IML})$ and $\mathrm{CA} 1$ combined with low ethylene (CA1+LE). The average ethylene concentration in the storage atmosphere of the treatments was 5.23 (CS), $1.12(\mathrm{CA} 1)$ and $<0.04$ $(\mathrm{CA} 1+\mathrm{LE}) \mu \mathrm{L} \mathrm{L}^{-1}$. The treatments of Experiment 2 were $\mathrm{CS}$, CA2 $\left(2 \mathrm{kPa}\right.$ of $\mathrm{O}_{2}+2 \mathrm{kPa}$ of $\left.\mathrm{CO}_{2}\right)$, CA2+1-MCP $\left(1 \mu \mathrm{L} \mathrm{L}^{-1}\right)$ and CA2+IML (2\%). The fruits of both experiments were stored at $0.5 \pm 0.1{ }^{\circ} \mathrm{C}$ and $96 \pm 2 \%$ of relative humidity.

Partial gas pressures were obtained by diluting $\mathrm{O}_{2}$ in the micro-chambers with $\mathrm{N}_{2}$ injection from a $\mathrm{N}_{2}$ separator that uses the pressure-swing adsorption principle. Daily analyses were carried out for the maintenance of partial gas pressures in the chambers, using an automatic gas control device (Kronenberger Climasul). The excess $\mathrm{CO}_{2}$ was absorbed by a potassium hydroxide solution $(40 \%)$, through which the gases from the micro-chambers were circulated.

IML was induced by a constant air humidity absorption in the micro-chamber, in order to achieve a fresh mass loss of $2 \%$ at the end of storage period. This procedure was carried out with a membrane pump, which circulates air from the micro-chamber interior to a container containing silica gel, according to the methodology described by Brackmann et al. (2007)

Removal of ethylene in the treatment low ethylene (LE) (ethylene $<0.04 \mu \mathrm{L} \mathrm{L}^{-1}$ ) was carried out 
with chemical absorption by adding packets containing potassium permanganate (one packet for each $3 \mathrm{~kg}$ of fruits) in the micro-chamber. Ethylene levels were monitored weekly by injecting $1 \mathrm{~mL}$ of gas from the chamber atmospheres into a gas chromatograph device (Varian ${ }^{\circledR} 3400 \mathrm{CX}$, Palo Alto, CA, USA), equipped with flame ionization detector and a $0.7-\mathrm{m}$ long Porapak $\mathrm{N}^{\circledR}$ column, using nitrogen as carrier gas. The temperatures used were $90{ }^{\circ} \mathrm{C}$ (column), $140{ }^{\circ} \mathrm{C}$ (injector) and $200{ }^{\circ} \mathrm{C}$ (detector).

The product SmartFresh ${ }^{\circledR}$ (0.14\% of $1-\mathrm{MCP}$, powder formulation) was used for the treatment with 1-MCP, applying $1.6 \mathrm{~g}$ of this product for each $\mathrm{m}^{3}$ of chamber to obtain $1 \mu \mathrm{L} \mathrm{L}^{-1}$ of $1-\mathrm{MCP}$. This product was placed in an airtight vial and solubilized in water at room temperature. Thereafter, the vial was introduced into the micro-chamber, and the solution was transferred to a Petri dish through a side opening and immediately sealed. The application of 1-MCP started one day after harvest and the fruits were subjected to this treatment for 24 hours.

The analyzes of the experiments were carried out after 55 days of storage and after 55 days of storage plus three days at room conditions $\left(23 \pm 5{ }^{\circ} \mathrm{C}\right.$ and $60 \pm 5 \% \mathrm{RH}$ ) (Experiment 1), and after 30 and 50 days of storage, after 30 days of storage plus 4 at room conditions, and after 50 days of storage plus 4 at room conditions (Experiment 2). The attributes evaluated were respiratory rate, ethylene production rate, flesh firmness, texture (pressures needed to epidermis rupture, flesh penetration and fruit compression), titratable acidity, soluble solids, red color index, epidermis color (hue angle, $h^{\circ}$ ), occurrence and severity of internal browning and occurrence of rotting and cracking.

Respiratory rates and ethylene production rates were determined by placing 15 fruits of each sample in an airtight 2.3-L container and subsequently, gas samples $(1000 \mu \mathrm{L})$ were taken from these containers through a septum and injected into a gas chromatograph device (Varian ${ }^{\circledR}$ CP-3800), equipped with a $3.0-\mathrm{m}$ long Porapak $\mathrm{N}^{\circledR}$ column (80-100 mesh), methanator and flame ionization detector. Temperatures of $45{ }^{\circ} \mathrm{C}$ (column), $120{ }^{\circ} \mathrm{C}$ (detector), $300{ }^{\circ} \mathrm{C}$ (methanator), and $110{ }^{\circ} \mathrm{C}$

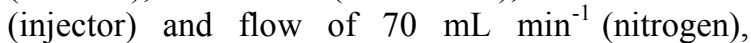
$30 \mathrm{~mL} \mathrm{~min}^{-1}$ (hydrogen) and $300 \mathrm{~mL} \mathrm{~min}^{-1}$ (synthetic air) were used. Respiratory rates were expressed as $\mathrm{nmol}$ of $\mathrm{CO}_{2} \mathrm{~kg}^{-1} \mathrm{~s}^{-1}$ and ethylene production rates as pmol of $\mathrm{C}_{2} \mathrm{H}_{4} \mathrm{~kg}^{-1} \mathrm{~s}^{-1}$.

Flesh firmness was determined $(\mathrm{N})$ in the equatorial region of the fruits, on two opposite sides, after removal of a small portion of the epidermis, using a penetrometer equipped with a $7.9 \mathrm{~mm}$ diameter tip.

Titratable acidity $\left(\mathrm{mEq} \quad 100 \mathrm{~mL}^{-1}\right)$ was evaluated in a $10-\mathrm{mL}$ sample of juice prepared from transversal slices taken from the equatorial region of the fruits and ground in a centrifuge. This sample was diluted in $90 \mathrm{~mL}$ of distilled water and titrated with $0.1 \mathrm{~N} \mathrm{NaOH}$ solution to $\mathrm{pH} 8.1$.

Soluble solids content $\left({ }^{\circ} \mathrm{Brix}\right)$ was determined by refractometry, using the juice extracted as described for titratable acidity, correcting the effect of temperature $\left(20^{\circ} \mathrm{C}\right)$.

Texture attributes (forces needed to epidermis rupture, flesh penetration and fruit compression) were analyzed in an electronic texturometer (TAXT-plus ${ }^{\circledR}$, Stable Micro Systems Ltd., UK). The evaluation of forces needed to epidermis rupture and flesh penetration was carried out using a PS2 tip, which was introduced into the pulp at a depth of $5 \mathrm{~mm}$ with speeds of 30 (pre-test) 5 (test) and 30 (post-test) $\mathrm{mm} \mathrm{s}^{-1}$, without removal of the epidermis. The force for fruit compression was determined using a $75-\mathrm{mm}$ diameter flat $\mathrm{P} / 75$ platform, applying increasing pressure up to a $5-\mathrm{mm}$ deformation on the fruit surface.

The red color index of the fruit red surface was evaluated with a scale of grades according to the fruit percentage of red pigmented surface, $0-25 \%$ (1), $26-50 \%$ (2), $51-75 \%$ (3) and $76-100 \%$ (4). This index was calculated by dividing the number of fruits in each grade by the total number of fruits of the sample.

The epidermis color was determined with a colorimeter (Minolta CR400) and readings were performed on the more and less red sides of the fruit, in the equatorial region. The results were expressed in hue angle $\left(h^{\circ}\right)$. The $h^{\circ}$ defines the basic coloration as $0^{\circ}=$ red, $90^{\circ}=$ yellow and $180^{\circ}=$ green .

The occurrence of rotting fruits was evaluated by counting affected fruits, which had lesions larger than $5 \mathrm{~mm}$ in diameter and characteristics of pathogen attack.

The occurrence of internal browning was visually evaluated on cross sections of the equatorial region of the fruit, by counting the fruits that showed internal browning, with results expressed in percentages $(\%)$.

The severity of internal browning was evaluated with a colorimeter (Minolta CR 400), in the median region of the fruit pulp, with results expressed in luminosity $(L)$, from 0 (black) to 100 (white).

A completely randomized experimental design, with four replications was used for Experiment 1 (experimental units consisting of 20 fruits), and five replications for Experiment 2 (experimental units consisting of 40 fruits). Data were subjected to analysis of variance (ANOVA). Data expressed in percentages were transformed by the arcsen formula $[(\mathrm{x}+0.5) / 100]^{1 / 2}$ before subjected to ANOVA. Tukey's test was used to compare the means of treatments $(p<0.05)$. 


\section{RESULTS AND DISCUSSION}

\section{Experiment $1-2010$}

The harvested fruits showed $50 \%$ of the epidermis surface covered with red color (Index 2), soluble solids (SS) of $14.0^{\circ} \mathrm{Brix}$, titratable acidity (AT) of $28.2 \mathrm{meq} 100 \mathrm{~mL}^{-1}$, flesh firmness of $49.9 \mathrm{~N}$, pressures needed to epidermis rupture of $10.8 \mathrm{~N}$, flesh penetration of $3.7 \mathrm{~N}$ and fruit compression of $113.6 \mathrm{~N}$.

After 55 days of storage plus three days at room conditions, the respiratory rate of the treatments was similar (data not shown).

The flesh firmness and texture attributes (forces to epidermis rupture, flesh penetration and fruit compression) of all treatments in CA1, at withdrawing from the chambers $\left(55^{\text {th }}\right.$ day of storage), were higher than those of fruits in CS. However, after three days at room conditions, fruits stored in CA1 combined with 1-methylcyclopropene (1-MCP), induction of mass loss (IML) and low ethylene (LE) maintained their flesh firmness and texture attributes higher than those of fruits in $\mathrm{CS}$ and CA1 (Table 1). The maintenance of flesh firmness of fruits in CA1+1-MPC was related to the effect of 1-MCP on the inhibition of ethylene action, since ethylene promotes activity of enzymes responsible for fruit softening (CANDAN, GRAEL; LARRIGAUDIÉRE, 2011; KHAN; SINGH, 2007). Alves et al. (2009, 2010b), Candan, Grael and Larrigaudiére (2011) and Manganaris et al. (2008), also observed delay in flesh firmness loss in plums due to the effect of $1-\mathrm{MCP}$, corroborating the results of the present work.

The greater flesh firmness of the fruits stored in CA1 with LE was due to the lower action of ethylene in the activation of enzymes responsible for fruit softening. A greater flesh firmness in fruits subjected to IML was also found in 'Gala' apples stored in CA (BRACKMANN et al., 2007) and 'Laetitia' plums in CS (ALVES et al., 2010b). IML caused a lower production of ethylene in 'Gala' apples, which may explain the greater flesh firmness of fruits stored with IML (BRACKMANN et al., 2007).

Table 1. Flesh firmness and texture attributes (forces to epidermis rupture, flesh penetration and fruit compression) of 'Laetitia' plums under cold storage $\left(21 \mathrm{kPa} \mathrm{O}_{2}+\mathrm{CO}_{2}<0.03 \mathrm{kPa}\right)(\mathrm{CS})$, controlled atmosphere (CA1) (1 kPa of $\mathrm{O}_{2}+1 \mathrm{kPa}$ of $\left.\mathrm{CO}_{2}\right)$, CA1 combined with 1-methylcyclopropene $\left(1 \mu \mathrm{L} \mathrm{L}^{-1}\right)(\mathrm{CA} 1+1-\mathrm{MCP})$, CA combined with induction of mass loss (2\%) (CA1+IML) and CA1 combined with low ethylene (ethylene $<0.04 \mu \mathrm{L} \mathrm{L}^{-1}$ de $\left.\mathrm{C}_{2} \mathrm{H}_{4}\right)(\mathrm{CA} 1+\mathrm{LE})$, after 55 days of storage $\left(0.5 \pm 0.1{ }^{\circ} \mathrm{C} ; 96 \pm 2 \% \mathrm{RH}\right)$ and after 55 days of storage plus three days at room conditions $\left(23 \pm 5{ }^{\circ} \mathrm{C} ; 60 \pm 5 \% \mathrm{RH}\right)$.

\begin{tabular}{|c|c|c|c|c|}
\hline Treatments & $\begin{array}{l}\text { Flesh firmness } \\
(\mathrm{N})\end{array}$ & $\begin{array}{l}\text { Force to epidermis } \\
\text { rupture }(\mathrm{N})\end{array}$ & $\begin{array}{l}\text { Force to flesh } \\
\text { penetration }(\mathrm{N})\end{array}$ & $\begin{array}{l}\text { Force to fru } \\
\text { compression }\end{array}$ \\
\hline \multicolumn{5}{|c|}{ After 55 days of storage (chambers opening) } \\
\hline $\mathrm{CS}$ & $22.53 b^{*}$ & $4.53 b$ & $1.12 b$ & $52.38 \mathrm{~b}$ \\
\hline CA1 & $41.44 \mathrm{a}$ & $10.25 \mathrm{a}$ & $2.59 \mathrm{a}$ & $131.48 \mathrm{a}$ \\
\hline $\mathrm{CA} 1+1-\mathrm{MCP}$ & $40.12 \mathrm{a}$ & $9.98 \mathrm{a}$ & $2.56 \mathrm{a}$ & $133.97 \mathrm{a}$ \\
\hline CA1 + IML & $39.29 \mathrm{a}$ & $10.60 \mathrm{a}$ & $2.48 \mathrm{a}$ & $137.23 \mathrm{a}$ \\
\hline $\mathrm{CA} 1+\mathrm{LE}$ & $39.24 \mathrm{a}$ & $9.50 \mathrm{a}$ & $2.38 \mathrm{a}$ & $149.26 \mathrm{a}$ \\
\hline CV (\%) & 10.30 & 8.89 & 16.44 & 8.20 \\
\hline
\end{tabular}

After 55 days of storage plus three days at room conditions

\begin{tabular}{lcccc} 
CS & $26.69 \mathrm{c}$ & $4.48 \mathrm{~d}$ & $1.05 \mathrm{~b}$ & $70.54 \mathrm{~d}$ \\
$\mathrm{CA} 1$ & $29.68 \mathrm{c}$ & $7.87 \mathrm{c}$ & $1.25 \mathrm{~b}$ & $125.93 \mathrm{c}$ \\
$\mathrm{CA} 1+1-\mathrm{MCP}$ & $42.03 \mathrm{a}$ & $10.97 \mathrm{a}$ & $2.15 \mathrm{a}$ & $181.48 \mathrm{a}$ \\
$\mathrm{CA} 1+\mathrm{IML}$ & $35.79 \mathrm{~b}$ & $9.76 \mathrm{~b}$ & $1.94 \mathrm{a}$ & $164.69 \mathrm{~b}$ \\
$\mathrm{CA} 1+\mathrm{LE}$ & $38.56 \mathrm{ab}$ & $10.24 \mathrm{~b}$ & $2.16 \mathrm{a}$ & $176.01 \mathrm{ab}$ \\
$\mathrm{CV}(\%)$ & 11.50 & 4.82 & 11.67 & 6.07 \\
\hline
\end{tabular}

*Means followed by the same letter in the columns do not differ by Tukey's test $(\mathrm{p}<0.05)$. 
Fruits in CA1 showed higher TA at withdrawing from the chambers than those in CS, regardless of the use of complementary techniques. After three days at room conditions, fruits in CA1+1-MCP had higher TA than those in CA1 and
CS, but they did not differ from those in CA1+IML and CA1+LE (Table 2). Alves et al. (2010a) and Argenta et al. (2003) also found higher TA in 'Laetitia' plums treated with 1-MCP.

Table 2. Titratable acidity, soluble solids and red color index (RCI) of 'Laetitia' plums under cold storage $(21 \mathrm{kPa}$ $\left.\mathrm{O}_{2}+\mathrm{CO}_{2}<0.03 \mathrm{kPa}\right)(\mathrm{CS})$, controlled atmosphere (CA1) $\left(1 \mathrm{kPa}\right.$ of $\mathrm{O}_{2}+1 \mathrm{kPa}$ of $\left.\mathrm{CO}_{2}\right)$, CA1 combined with 1-methylcyclopropene $\left(1 \mu \mathrm{L} \mathrm{L}^{-1}\right)(\mathrm{CA} 1+1-\mathrm{MCP}), \mathrm{CA}$ combined with induction of mass loss $(2 \%)(\mathrm{CA} 1+\mathrm{IML})$ and $\mathrm{CA} 1$ combined with low ethylene (ethylene $<0.04 \mu \mathrm{L} \mathrm{L}^{-1}$ de $\left.\mathrm{C}_{2} \mathrm{H}_{4}\right)(\mathrm{CA} 1+\mathrm{LE})$, after 55 days of storage $\left(0.5 \pm 0.1{ }^{\circ} \mathrm{C} ; 96 \pm 2 \% \mathrm{RH}\right)$ and after 55 days of storage plus three days at room conditions $\left(23 \pm 5^{\circ} \mathrm{C} ; 60 \pm 5 \% \mathrm{RH}\right)$.

\begin{tabular}{|c|c|c|c|}
\hline Treatments & $\begin{array}{l}\text { Titratable acidity } \\
\left(\text { meq } 100 \mathrm{~mL}^{-1}\right)\end{array}$ & Soluble solids (Brix) & Red color index $(\mathrm{RCI})-\left(1-4^{* *}\right)$ \\
\hline \multicolumn{4}{|c|}{ After 55 days of storage (chambers opening) } \\
\hline $\mathrm{CS}$ & $11.9 b^{*}$ & $9.4 \mathrm{a}$ & $3.6 \mathrm{a}$ \\
\hline CA1 & $18.6 \mathrm{a}$ & $8.9 \mathrm{ab}$ & $2.8 \mathrm{~b}$ \\
\hline $\mathrm{CA} 1+1-\mathrm{MCP}$ & $18.4 \mathrm{a}$ & $9.1 \mathrm{ab}$ & $2.6 \mathrm{~b}$ \\
\hline CA1 + IML & $18.1 \mathrm{a}$ & $8.8 \mathrm{ab}$ & $2.9 \mathrm{~b}$ \\
\hline $\mathrm{CA} 1+\mathrm{LE}$ & $18.6 \mathrm{a}$ & $8.5 b$ & $2.9 b$ \\
\hline $\mathrm{CV}(\%)$ & 12.7 & 6.0 & 8.8 \\
\hline \multicolumn{4}{|c|}{ After 55 days of storage plus three days at room conditions } \\
\hline $\mathrm{CS}$ & $11.3 \mathrm{c}$ & $8.8 \mathrm{a}$ & $3.8 \mathrm{a}$ \\
\hline CA1 & $15.0 \mathrm{~b}$ & $7.3 b$ & $3.5 b$ \\
\hline $\mathrm{CA} 1+1-\mathrm{MCP}$ & $18.0 \mathrm{a}$ & $7.4 b$ & $3.3 \mathrm{c}$ \\
\hline CA1 + IML & $17.6 \mathrm{ab}$ & $7.2 b$ & $3.5 b$ \\
\hline $\mathrm{CA} 1+\mathrm{LE}$ & $15.5 \mathrm{ab}$ & $7.0 \mathrm{~b}$ & $3.3 \mathrm{c}$ \\
\hline CV (\%) & 12.5 & 10.1 & 4.8 \\
\hline
\end{tabular}

*Means followed by the same letter in the columns do not differ by Tukey's test $(\mathrm{p}<0.05)$

$* *$ Red color index (RCI): $1=0$ to $25 \%$ red; $2=26$ to $50 \%$ red; $3=51$ to $75 \%$ red; $4=>75 \%$ red.

The SS contents of the fruits in CS at withdrawing from the chamber were significantly different than those in $\mathrm{CA} 1+\mathrm{LE}$. However, after three days at room conditions, the fruits in CA1, showed lower SS, regardless of the use of complementary techniques (Table 2). The treatments in which flesh firmness and texture attributes of fruits were lower, in general, had higher SS. The highest SS in CS are probably related to a higher content of soluble pectins, since these fruits had the lowest flesh firmness, confirming previous results that showed this inverse relationship between flesh firmness and SS content in 'Laetitia' plum (STEFFENS et al., 2011).

The red color index $(\mathrm{RCI})$ of the fruits in $\mathrm{CA} 1$ at withdrawing from the chamber was lower compared with those stored in CS. After three days at room conditions, fruits in $\mathrm{CA} 1+1-\mathrm{MCP}$ and CA1+LE had the lowest RCI (Table 2).

The results of epidermis color $\left(h^{\circ}\right)$ was similar to the RCI (data not shown). Candan, Grael and Larrigaudiére (2011) also found a delayed epidermis color evolution in 1-MCP in plum cultivars with climacteric peak of ethylene production, but not in cultivars with suppression of climacteric peak of ethylene production. The effect of 1-MCP and ethylene absorption on the maintenance of the plum epidermis coloration, combined with the results of Candan, Grael and Larrigaudiére (2011), show the epidermal color 
evolution of plums as a process dependent on the action of ethylene.

The occurrence of internal browning was high in all treatments $(>87 \%)$, however it was lower in the fruits in $\mathrm{CA} 1$ and $\mathrm{CA} 1+1-\mathrm{MCP}$ at withdrawing from the chamber. However, after three days at room conditions, the treatments showed no difference (Table 3). Internal browning is a process that can occur at low temperatures and long periods of storage, which seems to be aggravated by the action of ethylene (CANDAN; GRAEL; LARRIGAUDIÉRE, 2011).

The high occurrence of pulp browning in all treatments may be related to the prolonged storage period. Singh and Singh (2013a) also found a higher occurrence of internal browning in plums over the storage period. Steffens et al. (2014), evaluated several CA and found high occurrence of internal browning in 'Laetitia' plums stored for 60 days, regardless of the CA conditions.

Table 3. Occurrence and intensity of internal browning, rotting and cracking of 'Laetitia' plums under cold storage $\left(21 \mathrm{kPa} \mathrm{O}_{2}+\mathrm{CO}_{2}<0.03 \mathrm{kPa}\right)(\mathrm{CS})$, controlled atmosphere (CA1) $\left(1 \mathrm{kPa}\right.$ of $\mathrm{O}_{2}+1 \mathrm{kPa}$ of $\left.\mathrm{CO}_{2}\right)$, CA1 combined with 1-methylcyclopropene $\left(1 \mu \mathrm{L} \mathrm{L}^{-1}\right)(\mathrm{CA} 1+1-\mathrm{MCP})$, CA combined with induction of mass loss (2\%) (CA1+IML) and CA1 combined with low ethylene (ethylene $<0.04 \mu \mathrm{L} \mathrm{L}^{-1}$ de $\left.\mathrm{C}_{2} \mathrm{H}_{4}\right)(\mathrm{CA} 1+\mathrm{LE})$, after 55 days of storage $\left(0.5 \pm 0.1{ }^{\circ} \mathrm{C} ; 96 \pm 2 \% \mathrm{RH}\right)$ and after 55 days of storage plus three days at room conditions $\left(23 \pm 5^{\circ} \mathrm{C} ; 60 \pm 5 \% \mathrm{RH}\right)$.

Tratamentos

Rotting (\%)

Cracking (\%)

\begin{tabular}{|c|c|c|c|c|}
\hline \multicolumn{5}{|c|}{ After 55 days of storage (chambers opening) } \\
\hline $\mathrm{CS}$ & $100.0 \mathrm{a}^{*}$ & $40.1 \mathrm{c}$ & $50.0 \mathrm{a}$ & $82.5 \mathrm{a}$ \\
\hline CA1 & $88.5 b$ & $43.3 b$ & $1.9 \mathrm{c}$ & $0.6 \mathrm{~b}$ \\
\hline $\mathrm{CA} 1+1-\mathrm{MCP}$ & $87.3 b$ & $46.2 \mathrm{a}$ & $2.8 \mathrm{c}$ & $0.7 \mathrm{~b}$ \\
\hline CA1 + IML & $91.7 \mathrm{ab}$ & $48.5 \mathrm{a}$ & $17.7 \mathrm{~b}$ & $0.6 b$ \\
\hline $\mathrm{CA} 1+\mathrm{LE}$ & $95.0 \mathrm{ab}$ & $43.2 b$ & $2.5 \mathrm{c}$ & $0.6 b$ \\
\hline CV $(\%)$ & 13.2 & 4.0 & 30.1 & 30.3 \\
\hline \multicolumn{5}{|c|}{ After 55 days of storage plus three days at room conditions } \\
\hline $\mathrm{CS}$ & $100.0 \mathrm{a}$ & $40.3 \mathrm{c}$ & $36.1 \mathrm{a}$ & $93.7 \mathrm{a}$ \\
\hline CA1 & $93.4 \mathrm{a}$ & $40.5 \mathrm{c}$ & $22.1 \mathrm{a}$ & $0.1 b$ \\
\hline $\mathrm{CA} 1+1-\mathrm{MCP}$ & $96.1 \mathrm{a}$ & $45.6 \mathrm{a}$ & $15.1 \mathrm{a}$ & $1.3 b$ \\
\hline CA1 + IML & $97.4 \mathrm{a}$ & $45.7 \mathrm{a}$ & $10.7 \mathrm{a}$ & $0.1 b$ \\
\hline CA1 + LE & $96.3 \mathrm{a}$ & $43.2 b$ & $19.2 \mathrm{a}$ & $0.1 b$ \\
\hline CV (\%) & 9.3 & 3.7 & 40.1 & 33.2 \\
\hline
\end{tabular}

*Means followed by the same letter in the columns do not differ by Tukey's test $(\mathrm{p}<0.05)$.

The internal browning intensity (evaluated in terms of color parameter $L$ ) was lower in fruits in $\mathrm{CA} 1+1-\mathrm{MCP}$ and $\mathrm{CA} 1+\mathrm{IML}$ at withdrawing from the chamber, and also after three days at room conditions (Table 3). According to Corrêa et al. (2011), when the 'Laetitia' plum internal browning is at an early stage, these fruits may have good acceptability by consumers, and fruit flesh with $L$ of 48.7 had an acceptability above $50 \%$, however, fruit flesh with $L$ of 41.3 had $95 \%$ of rejection.
The fruits in CA1+IML had $L$ of 48.5 (at withdrawing from the chamber) and 45.6 (after three days at room conditions). The fruits in $\mathrm{CA} 1+1-\mathrm{MCP}$ had $L$ of 46.2 (at withdrawing from the chamber) and 45.6 (after three days at room conditions). These results of $L$ were close to those observed by Corrêa et al. (2011), who found reasonable acceptability for the fruits. The fruits in CS and CA1 had $L \leq 41.3$ after three days at room conditions, which according to Corrêa et al. (2011) would have high rejection by 
consumers.

All fruits in treatments with CA1 had lower occurrence of rotting and cracking at withdrawing from the chamber than those in CS. However, after three days at room conditions, there were differences in cracking, with lower occurrence in fruits from treatments with CA1 (Table 3). This lower cracking occurrence in CA1 was related to the less advanced maturity stage of fruits in CA1 compared with those in CS. Steffens et al. (2014) also found lower occurrence of rotting and cracking in fruits in CA1 compared with fruits in CS. The effect of CA on the reduction of rotting can be attributed to the low levels of $\mathrm{O}_{2}$ combined with high levels of $\mathrm{CO}_{2}$, which have a fungistatic effect, inhibiting spore germination and fungus growth during the storage period (VIEIRA et al., 2006).

\section{Experiment 2-2011}

The harvested fruits showed $50 \%$ of the epidermis surface covered with red color (Index 2), SS of $14.8^{\circ}$ Brix, TA of $26.0 \mathrm{meq} 100 \mathrm{~mL}^{-1}$, flesh firmness of $51.5 \mathrm{~N}$, pressures needed to epidermis rupture of $11.7 \mathrm{~N}$, flesh penetration of $3.4 \mathrm{~N}$, and fruit compression of $114.2 \mathrm{~N}$.

All fruits in CA2 had lower ethylene production rate than those in $\mathrm{CS}$ in all evaluation times (at withdrawing from the chambers after 30 and 50 days of storage, after 30 days of storage plus 4 at room conditions, and after 50 days of storage plus 4 at room conditions) (Table 4). The ethylene production in CA conditions was low due to the low partial pressure of $\mathrm{O}_{2}$ caused by low oxidation of 1-aminocyclopropane-1-carboxylic acid (ACC) to ethylene (BLANKENSHIP; DOLE, 2003). Moreover, the high partial pressure of $\mathrm{CO}_{2}$ reduces cell $\mathrm{pH}$, inhibiting the activity of the enzyme ACC oxidase, contributing to reduce ethylene biosynthesis (GORNY; KADER, 1996). The treatments CA2, $\mathrm{CA} 2+\mathrm{IML}$ and $\mathrm{CA} 2+1-\mathrm{MCP}$ were similar in ethylene production in all evaluation periods.

According to Gorny and Kader (1996), the low partial pressure of $\mathrm{O}_{2}$ reduces the respiratory activity. However, after 30 days of storage at withdrawing from the chambers, and also after four days at room conditions, the respiratory rate of fruits in CA2+1-MCP was lower than those in fruits in $\mathrm{CS}$, but not differing from the other treatments in CA2. After 50 days of storage, the respiratory rate of fruits was similar in all treatments, and after four days at room conditions, fruits in CA2 had lower respiratory rates than those in CS. These results show the effect of 1-MCP on preventing the binding of ethylene to the receptor, reducing the action of ethylene on the enzymes that act in the respiratory process.

Flesh firmness of all fruits in CA2 was, in general, higher than those in CS. The higher loss of flesh firmness in CS was related to the high ethylene production in fruits in this treatment. Corrêa et al. (2011) evaluated Laetitia plums and also found lower flesh firmness in treatments with higher ethylene production. Ethylene promotes the activity of enzymes responsible for fruit softening (CANDAN; GRAEL; LARRIGAUDIÉRE， 2011; KHAN; SINGH, 2007).

The results of pressures needed for epidermis rupture, pulp penetration and fruit compression were similar those of flesh firmness (data not shown).

The red color index (RCI) of all treatments after 30 days of storage were similar (Table 4). However, after four days at room conditions, fruits in $\mathrm{CA} 2+1-\mathrm{MCP}$ had lower index than those in $\mathrm{CS}$, but not differing from those in CA2+IML (Table 4). After 50 days of storage, the lowest RCI was found in fruits in $\mathrm{CA} 2+\mathrm{IML}$, but not differing from those in CA2 (Table 4).

After 50 days of storage plus four days at room conditions, all fruits in CA2 had lower RCI than those in CS (Table 4). The results of epidermis color $\left(h^{\circ}\right)$ was similar to those of RCI, showing no difference after the 30 days of storage. Fruits of the treatments in CA2 had, in general, higher $h^{\circ}$, i.e., less red color compared with fruits in CS (data not shown). The higher color evolution in CS may be related to the higher ethylene production of fruits in CS during storage. According to Argenta et al. (2003), processes responsible for color change in plums are dependent on ethylene. However, fruits in CA2+1-MCP showed no consistent differences to the other CA2 treatments. Similar results were found by Corrêa et al. (2011).

The highest occurrence and severity of internal browning in all evaluations was found in fruits in CS, which also had the lowest pulp luminosity $(L)$, indicating a greater intensity of internal browning (Table 5). Singh and Singh (2013a) and Steffens et al. (2014) also found lower internal browning in fruits in CA compared with fruits in CS. The effect of CA on reducing internal browning is related to the increase of antioxidant metabolism and suppression of the oxidative process (SINGH; SINGH, 2013a).

Occurrence and severity of internal browning in fruits in CA2 after 30 days of storage was similar. 
Table 4. Respiratory rate, ethylene production, pulp firmness and red color index (RCI) of 'Laetitia' plums under cold storage ( $21 \mathrm{kPa} \mathrm{O}_{2}+\mathrm{CO}_{2}<0.03 \mathrm{kPa}$ ) (CS), controlled atmosphere (CA2) ( $2 \mathrm{kPa}$ of $\mathrm{O}_{2}+2 \mathrm{kPa}$ of $\left.\mathrm{CO}_{2}\right)$, CA1 combined with 1-methylcyclopropene $\left(1 \mu \mathrm{L} \mathrm{L}^{-1}\right)(\mathrm{CA} 2+1-\mathrm{MCP})$ and $\mathrm{CA}$ combined with induction of mass loss $(2 \%)(\mathrm{CA} 2+\mathrm{IML})$, after 30 and 50 days of storage $\left(0.5 \pm 0.1{ }^{\circ} \mathrm{C} ; 96 \pm 2 \% \mathrm{RH}\right)$ and plus three days at room conditions $\left(23 \pm 5{ }^{\circ} \mathrm{C} ; 60 \pm 5 \% \mathrm{RH}\right)$.

\begin{tabular}{|c|c|c|c|c|}
\hline Treatments & $\begin{array}{l}\text { Ethylene production } \\
\left(\rho \mathrm{\rho mol} \mathrm{C}_{2} \mathrm{H}_{4} \mathrm{~kg}^{-1} \mathrm{~s}^{-1}\right)\end{array}$ & $\begin{array}{l}\text { Respiratory rate } \\
\left(\eta \mathrm{mol} \mathrm{CO} \mathrm{Kg}^{-1} \mathrm{~s}^{-1}\right)\end{array}$ & $\begin{array}{l}\text { Flesh firmness } \\
\text { (N) }\end{array}$ & $\mathrm{RCI}(1-4)$ \\
\hline \multicolumn{5}{|c|}{ After 30 days of storage plus (chambers opening) } \\
\hline CS & $21.9 a^{*}$ & $351.1 \mathrm{a}$ & $41.3 b$ & $2.4 \mathrm{a}$ \\
\hline CA2 & $2.3 b$ & $246.0 \mathrm{ab}$ & $46.9 \mathrm{ab}$ & $2.5 \mathrm{a}$ \\
\hline CA2+IML & $1.6 b$ & $225.3 \mathrm{ab}$ & $46.8 \mathrm{ab}$ & $2.4 \mathrm{a}$ \\
\hline $\mathrm{CA} 2+1-\mathrm{MCP}$ & $2.7 b$ & $202.1 b$ & $49.8 \mathrm{a}$ & $2.5 \mathrm{a}$ \\
\hline $\mathrm{CV}(\%)$ & 70.8 & 27.6 & 7.3 & 7.7 \\
\hline \multicolumn{5}{|c|}{ After 30 days of storage plus four days at room conditions } \\
\hline $\mathrm{CS}$ & $53.7 \mathrm{a}$ & $368.4 \mathrm{a}$ & $8.3 \mathrm{~b}$ & $3.7 \mathrm{a}$ \\
\hline CA2 & $2.0 \mathrm{~b}$ & $209.0 \mathrm{ab}$ & $25.4 \mathrm{a}$ & $3.1 \mathrm{~b}$ \\
\hline CA2+IML & $2.5 b$ & $225.2 \mathrm{ab}$ & $26.9 \mathrm{a}$ & $3.0 \mathrm{bc}$ \\
\hline $\mathrm{CA} 2+1-\mathrm{MCP}$ & $2.0 \mathrm{~b}$ & $183.6 \mathrm{~b}$ & $29.4 \mathrm{a}$ & $2.9 \mathrm{c}$ \\
\hline $\mathrm{CV}(\%)$ & 126.2 & 39.8 & 13.6 & 4.0 \\
\hline \multicolumn{5}{|c|}{ After 50 days of storage (chambers opening) } \\
\hline $\mathrm{CS}$ & $\mathrm{ND}^{* * *}$ & $347.6 \mathrm{a}$ & $25.9 \mathrm{~b}$ & $2.8 \mathrm{a}$ \\
\hline CA2 & ND & $269.1 \mathrm{a}$ & $41.0 \mathrm{a}$ & $2.3 \mathrm{ab}$ \\
\hline CA2+IML & ND & $258.7 \mathrm{a}$ & $44.2 \mathrm{a}$ & $2.3 b$ \\
\hline $\mathrm{CA} 2+1-\mathrm{MCP}$ & ND & $213.6 \mathrm{a}$ & $42.6 \mathrm{a}$ & $2.4 \mathrm{ab}$ \\
\hline $\mathrm{CV}(\%)$ & - & 45.5 & 14.1 & 9.9 \\
\hline \multicolumn{5}{|c|}{ After 50 days of storage plus four days at room conditions } \\
\hline CS & $24.7 \mathrm{a}$ & 247.1a & $24.2 b$ & $3.0 \mathrm{a}$ \\
\hline CA2 & $12.8 b$ & $128.2 \mathrm{~b}$ & $37.7 \mathrm{a}$ & $2.4 \mathrm{~b}$ \\
\hline $\mathrm{CA} 2+\mathrm{IML}$ & $16.6 \mathrm{~b}$ & $165.1 b$ & $36.4 \mathrm{a}$ & $2.7 \mathrm{~b}$ \\
\hline $\mathrm{CA} 2+1-\mathrm{MCP}$ & $14.4 \mathrm{~b}$ & $130.5 b$ & $41.1 \mathrm{a}$ & $2.6 \mathrm{~b}$ \\
\hline $\mathrm{CV}(\%)$ & 55.9 & 25.7 & 14.6 & 9.7 \\
\hline
\end{tabular}

*Means followed by the same letter in the columns do not differ by Tukey's test $(p<0.05)$.

In general, the fruits in CA2+1-MCP had the lowest occurrence and severity of internal browning. Fruits in CA2+IML had lower occurrence and severity of internal browning than those in CA2 after 50 days of storage, but not differing from those in $\mathrm{CA} 2+1-\mathrm{MCP}$ (Table 5). Fruits in CA2, after 50 days of storage plus four days at room conditions, had differences in flesh luminosity, with fruits in CA2+1 -MCP having higher $L$ compared with those in CA2 (Table 5). These results show that the use of 1-MCP promotes an additional positive result to $\mathrm{CA}$ in controlling internal browning occurrence. According to Argenta et al. (2003), Laetitia plums show internal browning mainly after 30 days of storage. The high occurrence of internal browning in CS may be related to the high rate of ethylene production in this treatment (Table 5).

The variables rotting and cracking showed similar results in all treatments (data not shown). 
Table 5. Occurrence and severity of internal browning and internal browning intensity $(L)$ of 'Laetitia' plums under cold storage ( $21 \mathrm{kPa} \mathrm{O}_{2}+\mathrm{CO}_{2}<0.03 \mathrm{kPa}$ ) (CS), controlled atmosphere (CA2) ( $2 \mathrm{kPa}$ of $\mathrm{O}_{2}+2 \mathrm{kPa}$ of $\left.\mathrm{CO}_{2}\right)$, CA2 combined with 1-methylcyclopropene $\left(1 \mu \mathrm{L} \mathrm{L}^{-1}\right)(\mathrm{CA} 2+1-\mathrm{MCP})$ and $\mathrm{CA}$ combined with induction of mass loss $(2 \%)(\mathrm{CA} 2+\mathrm{IML})$, after 30 and 50 days of storage $\left(0.5 \pm 0.1{ }^{\circ} \mathrm{C} ; 96 \pm 2 \% \mathrm{RH}\right)$ and plus three days at room conditions $\left(23 \pm 5{ }^{\circ} \mathrm{C} ; 60 \pm 5 \% \mathrm{RH}\right)$.

\begin{tabular}{|c|c|c|c|}
\hline Treatments & Internal browning $(\%)$ & $\begin{array}{l}\text { Severity of internal browning (1- } \\
\left.5^{* *}\right)\end{array}$ & $\begin{array}{c}\text { Internal browning intensity } \\
(L)\end{array}$ \\
\hline \multicolumn{4}{|c|}{ After 30 days of storage (chambers opening) } \\
\hline $\mathrm{CS}$ & $39.4 a^{*}$ & $0.97 \mathrm{a}$ & $55.2 b$ \\
\hline $\mathrm{CA} 2$ & $21.0 \mathrm{~b}$ & $0.45 b$ & $59.8 \mathrm{a}$ \\
\hline $\mathrm{CA} 2+\mathrm{IML}$ & $20.2 b$ & $0.54 \mathrm{~b}$ & $60.9 \mathrm{a}$ \\
\hline $\mathrm{CA} 2+1-\mathrm{MCP}$ & $19.7 b$ & $0.45 b$ & $60.9 \mathrm{a}$ \\
\hline $\mathrm{CV}(\%)$ & 19.3 & 8.8 & 2.0 \\
\hline \multicolumn{4}{|c|}{ After 30 days of storage plus four days at room conditions } \\
\hline $\mathrm{CS}$ & $66.9 \mathrm{a}$ & $1.67 \mathrm{a}$ & $53.8 \mathrm{a}$ \\
\hline $\mathrm{CA} 2$ & $4.0 \mathrm{~b}$ & $0.29 b$ & $53.4 \mathrm{a}$ \\
\hline CA2+IML & $5.6 \mathrm{~b}$ & $0.28 b$ & $54.5 \mathrm{a}$ \\
\hline $\mathrm{CA} 2+1-\mathrm{MCP}$ & $1.5 \mathrm{c}$ & $0.03 \mathrm{c}$ & $54.9 \mathrm{a}$ \\
\hline CV $(\%)$ & 26.7 & 58.0 & 5.5 \\
\hline \multicolumn{4}{|c|}{ After 50 days of storage (chambers opening) } \\
\hline $\mathrm{CS}$ & $100.0 \mathrm{a}$ & $2.61 \mathrm{a}$ & $40.8 \mathrm{~b}$ \\
\hline CA2 & $77.1 \mathrm{~b}$ & $2.49 \mathrm{a}$ & $53.2 \mathrm{a}$ \\
\hline $\mathrm{CA} 2+\mathrm{IML}$ & $55.2 \mathrm{c}$ & $1.60 \mathrm{~b}$ & $54.1 \mathrm{a}$ \\
\hline $\mathrm{CA} 2+1-\mathrm{MCP}$ & $58.0 \mathrm{c}$ & $1.43 b$ & $54.5 \mathrm{a}$ \\
\hline $\mathrm{CV}(\%)$ & 13.2 & 6.6 & 3.1 \\
\hline \multicolumn{4}{|c|}{ After 50 days of storage plus four days at room conditions } \\
\hline $\mathrm{CS}$ & $100.0 \mathrm{a}$ & $3.90 \mathrm{a}$ & $49.3 \mathrm{c}$ \\
\hline CA2 & $72.6 b$ & $3.10 \mathrm{~b}$ & $52.4 \mathrm{~b}$ \\
\hline $\mathrm{CA} 2+\mathrm{IML}$ & $67.8 \mathrm{~b}$ & $2.89 \mathrm{~b}$ & $54.5 \mathrm{ab}$ \\
\hline $\mathrm{CA} 2+1-\mathrm{MCP}$ & $42.3 \mathrm{c}$ & $1.33 \mathrm{c}$ & $55.1 \mathrm{a}$ \\
\hline CV $(\%)$ & 11.2 & 10.1 & 2.6 \\
\hline
\end{tabular}

*Means followed by the same letter in the columns do not differ by Tukey's test $(\mathrm{p}<0.05)$.

$* *$ Internal browning severity: $0=$ fruits without internal browning, $1=$ up to $10 \%, 2=11$ to $30 \%, 3=31$ to $50 \%, 4=51$ to $80 \%$, and $5=$ more than $80 \%$ of flesh browning.

\section{CONCLUSION}

Controlled atmosphere delayed ripening in both evaluated atmospheres and reduced the internal browning of the 'Laetitia' plum, especially in the conditions of $2 \mathrm{kPa} \mathrm{O}_{2}+2 \mathrm{kPa} \mathrm{CO}$.

Treatments with 1-MCP, induction of mass loss and low ethylene had additional effects to the controlled atmosphere (CA) $\left(1 \mathrm{kPa}\right.$ of $\mathrm{O}_{2}+1 \mathrm{kPa}$ of $\mathrm{CO}_{2}$ ) on the maintenance of flesh consistency.

Treatments with 1-MCP, regardless of the CA condition, and treatment with IML in the atmosphere of $1 \mathrm{kPa}$ of $\mathrm{O}_{2}+1 \mathrm{kPa}$ of $\mathrm{CO}_{2}$, reduced internal browning.

\section{ACKNOWLEDGEMENTS}

The authors thank the National Council for Scientific and Technological Development (CNPq) and the Foundation for Research and Innovation Support of the State of Santa Catarina (FAPESC) for financial support.

\section{REFERENCES}

ALVES, E. O. et al. Manejo do etileno durante o armazenamento de ameixas 'Laetitia' em atmosfera controlada. Ciência Rural, Santa Maria, v. 39, n. 9, p. $2445-2451,2009$.

ALVES, E. O. et al. Qualidade de ameixas 'Laetitia' em função da temperatura e da atmosfera de armazenamento. Revista Brasileira de 
Fruticultura, Jaboticabal, v. 32, n. 4, p. 1018-1027, 2010a.

ALVES, E. O. et al. Armazenamento refrigerado de ameixas 'Laetitia' com uso de 1-MCP e indução de perda de massa fresca. Ciência Rural, Santa Maria, v. 40 , n. 1, p. 30-36. 2010 b.

ARGENTA, L. C. et al. Ripening and quality of 'Laetitia' plums following harvest and cold storage as affected by inhibition of ethylene action. Pesquisa Agropecuária Brasileira, Brasília, v. 38, n. 10, p. 1139-1148, 2003.

BLANKENSHIP, S. M.; DOLE, J. M. 1methylcyclopropene: a review. Postharvest Biology Technology, Amsterdam, v. 28, n. 1, p. 1-25, 2003.

BRACKMANN, A. et al. Indução da perda de massa fresca e a ocorrência de distúrbios fisiológicos em maçãs 'Royal Gala' durante o armazenamento em atmosfera controlada. Revista Brasileira de Armazenamento, Viçosa, v. 32, n. 1, p. 87-92, 2007.

BRACKMANN, A. et al. Effect of growth regulators on 'Brookfield' apple gas diffusion and metabolism under controlled atmosphere storage. Pesquisa Agropecuária Brasileira, Brasília, v. 49, n. 5, p. 323-329, 2014.

CANDAN, A. P.; GRAEL, J.; LARRIGAUDIÉRE, C. Postharvest quality and chilling injury of plums: benefits of 1-methylcyclopropene. Spanish Journal of Agricultural Research, Madrid, v. 9, n. 2, p. 554 $-564,2011$

CORRÊA, T. R. et al. Ameixas 'Laetitia' armazenadas em atmosferas controlada e modificada ativa com manejo do etileno. Revista Brasileira de Fruticultura, Jaboticabal, v. 33, n. 3, p. 723-729, 2011.

GORNY, J. R.; KADER, A. A. Controlledatmosphere suppression of ACC synthase and ACC oxidase in 'Golden Delicious' apples during longterm cold storage. Journal of the American Society for Horticultural Science, Alexandria, v. 121, n. 4, p. 751-755, 1996.

KHAN, A. S.; SINGH Z. 1-MCP regulates ethylene biosynthesis and fruit softening during ripening of 'Tegan Blue' plum. Postharvest Biology and Technology, Amsterdam, v. 43, n. 3, p. 298-306, 2007.

MANGANARIS, G. A. et al. Novel 1methycyclopropene immersion formulation extends shelf life of advanced maturity 'Joanna Red' plums
(Prunus salicina Lindell). Postharvest Biology and Technology, Amsterdam, v. 47, n. 3, p. 429-433, 2008.

SINGH, S. P.; SINGH, Z. Role of membrane lipid peroxidation, enzymatic and non-enzymatic antioxidative systems in the development of chilling injury in japanese plums. Journal of the American Society for Horticultural Science, Alexandria, v. 137, n. 6, p. 473-481. 2012.

SINGH, S. P.; SINGH, Z. Controlled and modified atmospheres influence chilling injury, fruit quality and antioxidative system of japanese plums (Prunus salicina Lindell). International Journal of Food Science and Technology, Oxford, v. 48, n. 2, p. 363 $-374,2013 a$.

SINGH, S. P.; SINGH, Z. Postharvest cold storageinduced oxidative stress in Japanese plums (Prunus salicina Lindl. cv. Amber Jewel) in relation to harvest maturity. Australian Journal of Crop Science, Queensland, v. 7, n. 3, p. 391-400, 2013 b.

STEFFENS, C. A. et al. Maturação e qualidade pós-colheita de ameixas 'Laetitia' com a aplicação pré-colheita de AVG e $\mathrm{GA}_{3}$. Revista Brasileira de Fruticultura, Jaboticabal, v. 33, n. 1, p. 21-31, 2011

STEFFENS, C. A. et al. Condições de atmosfera controlada para o armazenamento de ameixas 'Laetitia' tratadas com 1-metilciclopropeno. Revista Ciência Agronômica, Fortaleza, v. 44, n. 4, p. 750$756,2013$.

STEFFENS, C. A. et al. Fruit quality preservation of 'Laetitia' plums under controlled atmosphere storage. Annals of the Brazilian Academy of Sciences, Rio de Janeiro, v. 86, n. 1, p. 485-494, 2014.

VIEIRA, D. G. et al. Crescimento in vitro de fungos (Colletotrichum gloeosporioides e Cladosporium cladosporioides) isolados de frutos do mamoeiro, sob atmosfera controlada e refrigeração. Revista Brasileira de Fruticultura, Jaboticabal, v. 28, n. 3, p. 387-390, 2006. 